Original Article

\title{
Birthplace of homeopathy: Hahnemann's house in Torgau, then and now
}

\author{
Peter Alex \\ Internationales Homöopathiekolleg Torgau, Germany
}

\begin{abstract}
The history of the house that Samuel Hahnemann and his family inhabited during the years from 1804 until 1811 is sketched out. Interesting details of the Torgau years - one of the most productive stages in Hahnemann's life - are highlighted. A summary of the history of homeopathy in Saxony is presented. The International Homeopathic College, a charity that works in research, teaching and practice of the Hahnemannian method in his former house is introduced.
\end{abstract}

Kewwords: Hahnemann's house; Torgau; history

\section{Hahnemann's journey to Torgau}

If his biographers made the count right, Samuel Hahnemann moved at least 25 times in the course of his 88 years of life. In the beginning, he roamed over half of Europe in pursuit of his studies, which was not exceptional at that time. In 1775, he left Meissen, the city of his birth, for Leipzig, where he took university training. After that he went to Vienna then to Hermannstadt (present day Sibiu, Romania) and finally to Erlangen, where he was awarded his doctorate in medicine. In 1780 he spent further time in Leipzig studying chemistry.

In 1781, Hahnemann set himself up as a pharmacist in Dessau. There he met Henriette, the daughter of Küchler, his pharmacy teacher. The two were married in 1782. From this time on the couple led an itinerant existence, which took them in the course of 23 years all over Saxony, Thüringia and Niedersachsen.

For one thing, Hahnemann was constantly in search of a means to treat sickness in good conscience, without (as in the materialistic medicine of then and now) inflicting iatrogenic "side-effects." But Hahnemann was also trying to find a position to ensure a livelihood for himself and his rapidly growing family.

Although the young couple must have found the first years quite challenging, they appear to have coped with things in loving companionship. Since Hahnemann's Autobiography consists of only four pages, encompassing the entire first two-thirds of his life, what we know of his daily routine comes mostly from letters and contemporary accounts.
Many of these anecdotes can be traced back to Hahnemann's grandson, Leopold Süss [1]. As a child, Süss lived with his mother for some time at his grandfather's house in Köthen. It was from three of Hahnemann's daughters who were living there that he learned so many details about the difficult years. Süss later practiced as a homeopathic physician in London, and he may be taken as the source for Dudgeons' own anecdotes.

In these years Hahnemann alternated between writing, translating and his medical duties. He pursued every possible source of income. Since he moved so often, it was not easy for his patients to track him down, and they had to be satisfied with follow-up consultations by mail. But for all these trials and tribulations, Hahnemann never once lost sight of his goal to set medicine on a rational footing.

Through his many publications, as much in the popular press as in the specialist world of medicine, pharmacy and chemistry, Hahnemann became so well known, that wherever he went a crowd already awaited him. His income grew correspondingly.

In a letter to a friend [1], Hahnemann records that in 1801 he had a house built in Eilenburg, and that he had earlier bought a place in Machern where he resided. But here again the Hahnemanns were to occupy this house for only two years, before moving on. Undoubtedly the Hahnemanns were preoccupied with concerns other than recording their experiences while on the move. There remain some blank spaces even in the biography by Richard Haehl [1], which appeared only after many years of 
research in the original sources. In these instances we simply do not know where Hahnemann lived. There is good reason to assume that the Hahnemanns (who with nine children did not make a small household, after all) simply lodged at inns in these new places, until Hahnemann could find and acquire a suitable dwelling.

From the contract of purchase [2] (figure 1) there is evidence that Hahnemann bought quite a large farm in Schildau (about $15 \mathrm{~km}$ from Torgau) in the spring of 1804 .

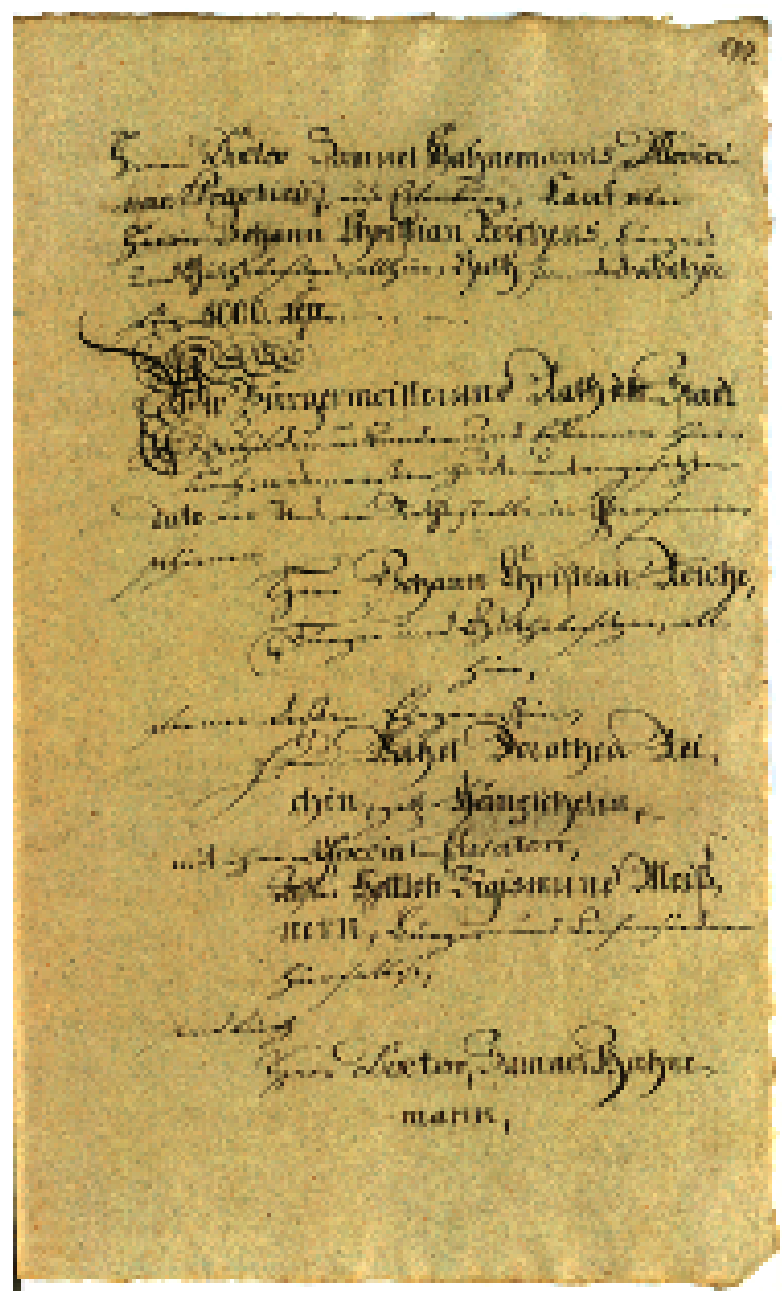

Figure 1: contract of purchase

Yet the remote place did not yield enough people to his practice, so Hahnemann traded the farm in for a decent house in nearby Torgau, which had been the Saxon royal seat in previous times. And there he acquired "a house with an entranceway and garden" [1].

\section{The house at number 3 Parish Street}

The name Pfarrstraße (Parish Street) derives from the rectory of the cathedral, located at one end of the street (figures 2 and 3 ).

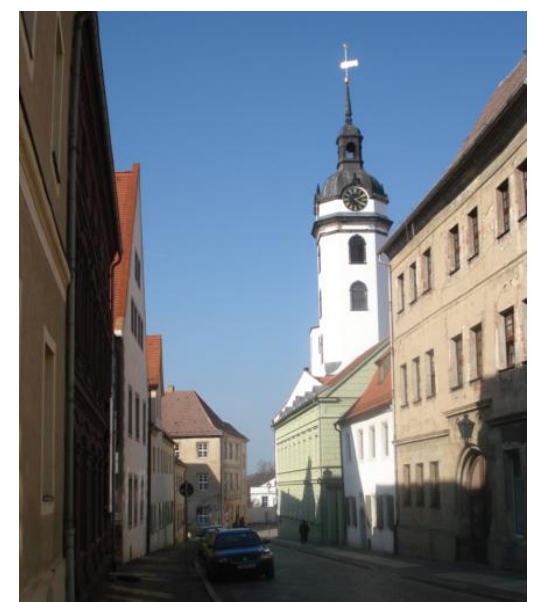

Figure 2: Pfarrstraße

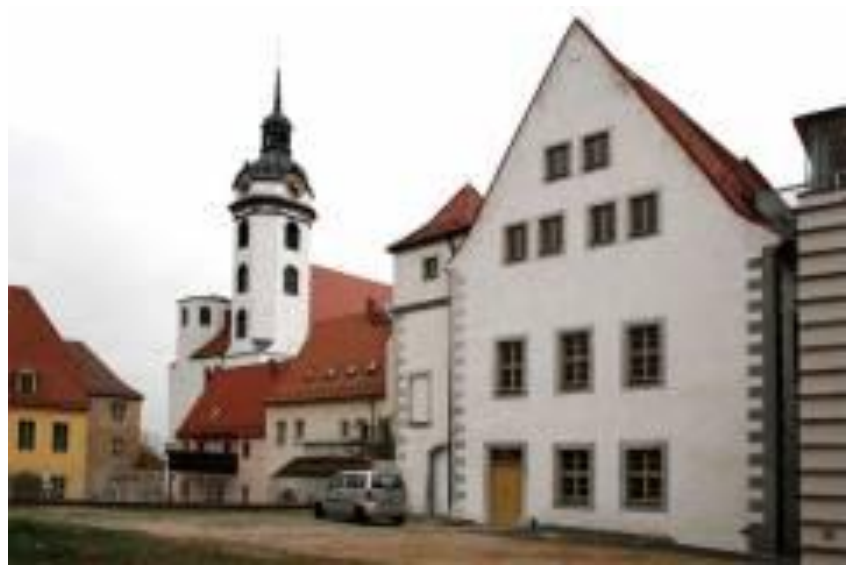

Figure 3: Rearview of Hahnemann's House and the Church of St. Mary's.

The earliest known name for this street was Nun Lane, reflecting the fact that a cloister stood on this very location back in the $13^{\text {th }}$ century. Even today, a portion of the lots in the borough remain church property. In the $15^{\text {th }}$ century the remaining portion was given as a fief to nobles in the service of the Saxon Elector. The earliest documented owner (and probably also the one who built the house) was Nickel von Holdaw (according to a record from 1474). In 1488 Michael Reppitzsch, the elector's chamberlain, is mentioned. From Nickel Holdaw he bought a property as a "free-house" by decree of the Elector. This he converted into a hereditary estate. [3]

A "free-house" was, as the name implies, exempt from any taxes or duties imposed by the city. If at all, the only taxes were those paid to the sovereign. This exemption seems to have applied right down to Hahnemann's time. 
A tree-ring analysis of the original roof-beams yields 1485 as the felling year. Presumably the structure would have been fully framed within a few years of that date. In 1535 the house was transferred from the possession of the widow, Barbara Reppitzsch, to a family by the name of von Minckwitz. Hans von Minckwitz was an adviser to the Saxon Elector, Friedrich the Wise, who earned his place in history as a friend and patron of Martin Luther [3].

After the turn of the $18^{\text {th }}$ century, the building frequently changed hands. From an auctioneer's record, dated 1796, we know quite accurately how it looked around the time when Hahnemann acquired it in 1804:

"At the entrance / a vaulted entrance gate with double doors, besides which an entryway with door. Upon entering the house / a vestibule on the right hand, with a wroughtiron latticed window. / A parlor with 3 windows, one provided with a wrought-iron lattice, in which / there is a large black tiled oven with a metal fire-box in an adjoining alcove / A chamber with 1 window and 1 door leading into the vestibule / A floor-covering in front of the stove in the parlour, having a door with tin fittings / To the left hand opposite the parlor / a paneled kitchen in which there is a window with wrought-iron latticework, before which / a cook-stove with a metal plate, under which a bath barrel, on the stove / a baking oven.

Off the kitchen / a pantry with a metal door and a small window, outfitted with an iron grill / A stone spiral staircase, which leads to the upper story and attic, but which is in bad shape and almost unusable.

At the entry to which (the upper story), a hallway with 2 windows and a big chimney, somewhat adaptable, beside which on the right hand, / a chamber with 2 windows and a iron oven with white tiled surface. Nearby on the right hand / a chamber with 2 windows and 1 iron oven with a white earthenware top, and to the right of that / a small chamber with 1 window / On the left hand a small room with 1 widow and an old earthernware tiled-oven.

Beside the first parlor, a chamber with 1 window and next to that a little room with 1 chimney, with an iron oven surfaced with blue and white earthenware; and in the same chamber 3 windows, 2 of them with halfshutters.

Outside the vestibule, a roofed hallway with 2 privies / On this floor, two chambers that have been boarded up. The floor is half stampedearth floor, half planked. I Above this floor is yet / another floor, but without floor boards / The clay-tiled roof is in disrepair and needs reroofing.

Next to the living quarters / a good double cellar, which can be entered either through the living room or from the outside.

Opposite the main house / a shed with servant quarters inside / A well with iron pump handles.

One outbuilding holding /a cart /shed /fire wood /enclosure, cow-stall and horse-stall, above which /a hayloft, the roof being covered with clay tiles. A pig-barn roofed with clay tiles.

Finally behind the main house, there is a vegetable garden, 28 yards long and 23 yards wide, surrounded by lattice fencing, within which stand several fruit trees, and there are also vines strung out." [3]

By the time Hahnemann acquired the property in 1804, the original renaissance interior was no longer in style. The wide window arches, which had been embellished with murals, were reduced down to little recessed niches. In compensation, they decorated the ceiling with stucco and the doors bore delicate baroque hardware.

Through the current restoration some very beautiful details lasting down through several centuries are being once again brought to light. Even during Hahnemann's time the spiral staircase, made from quarry sandstone, was described as "in bad shape and almost unusable." As the tower housing the staircase had bent over 350 years ago, it needed to be fixed with concrete injections during the restoration in 2007 (figure 4).

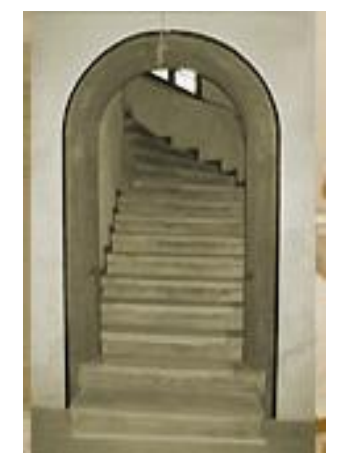

Figure 4: Staircase

For over 500 years this house served as a dwelling place. But finally in the 1970s, under the German Democratic Republic. it fell into such disrepair that it became uninhabitable. With the roof leaking, the city of Torgau considered tearing the place down. However, in 1992 people were made aware of the historical uniqueness of the house at number 3 Parish Street. From all the rain leaking in, the 
plaster in places had peeled away from the wall, revealing the first of a series of late Gothic murals.
These proved to be the oldest domestic murals found anywhere in Saxony (figure 5).
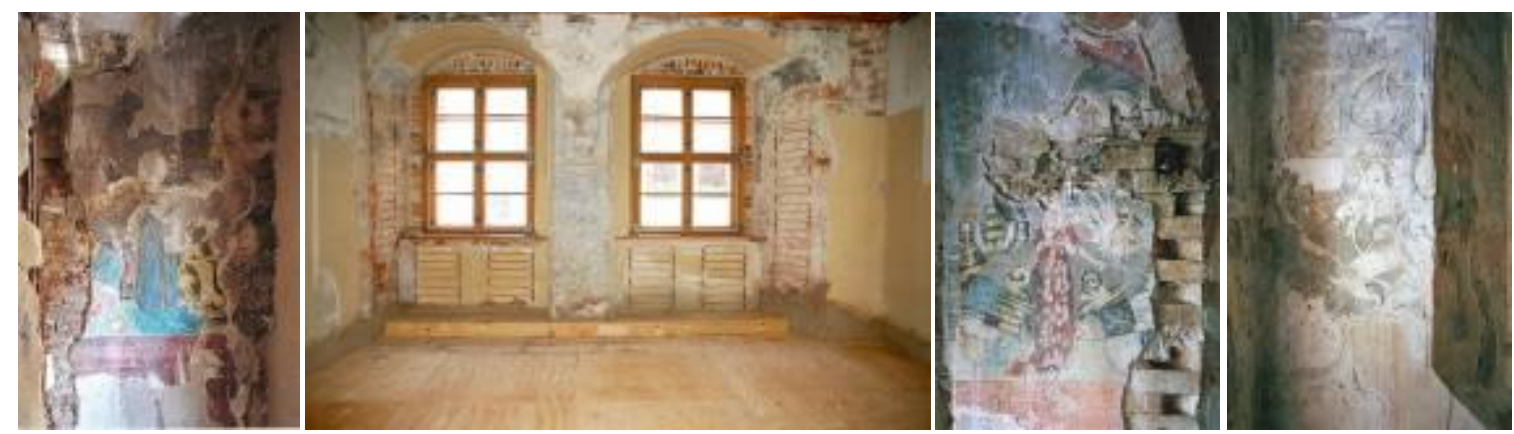

Figure 5: Murals in Hahnemann's House

In 1997, through a comparison of property registers and other records, the Torgau teacher, Karl-Heinz Lange, established without doubt that the house at what is now 3 Parish Street was actually the dwelling where Hahnemann had lived with his family from around Christmas 1804 to 1811.

Hahnemann practiced there as a physician, and it was there that he wrote several of those works which had a lasting impact right down to the present day.

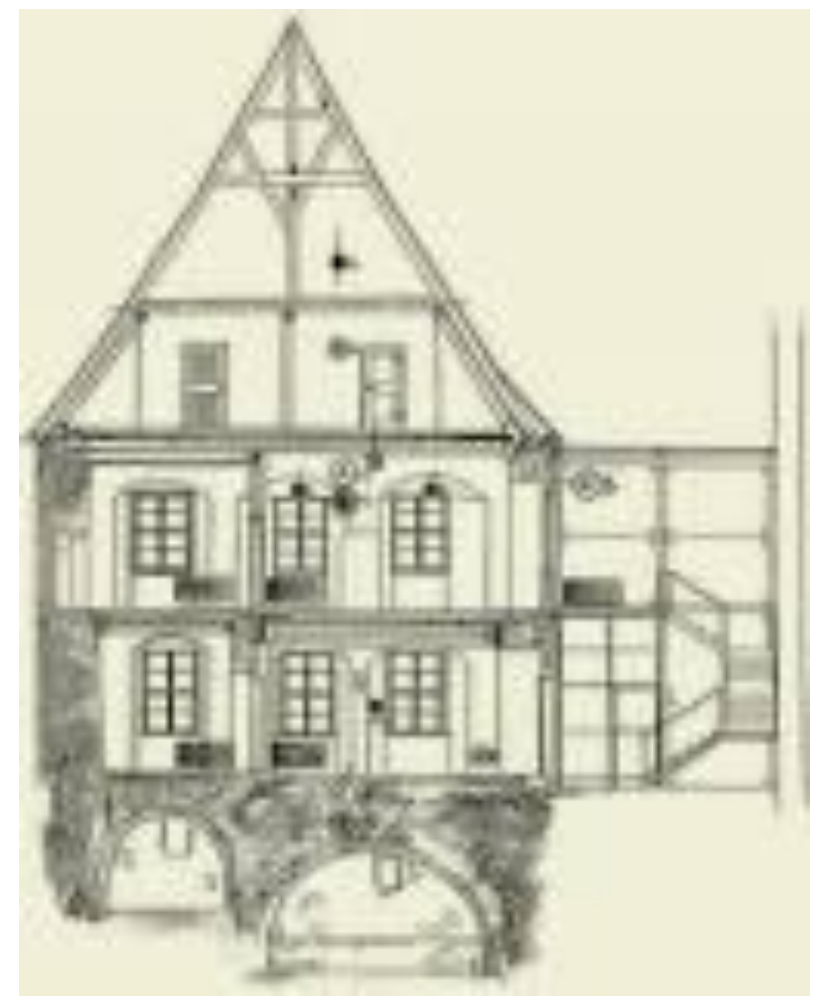

Figure 6: Schematic profile of Hahnemann's House with the modern staircase and lift attached to the right

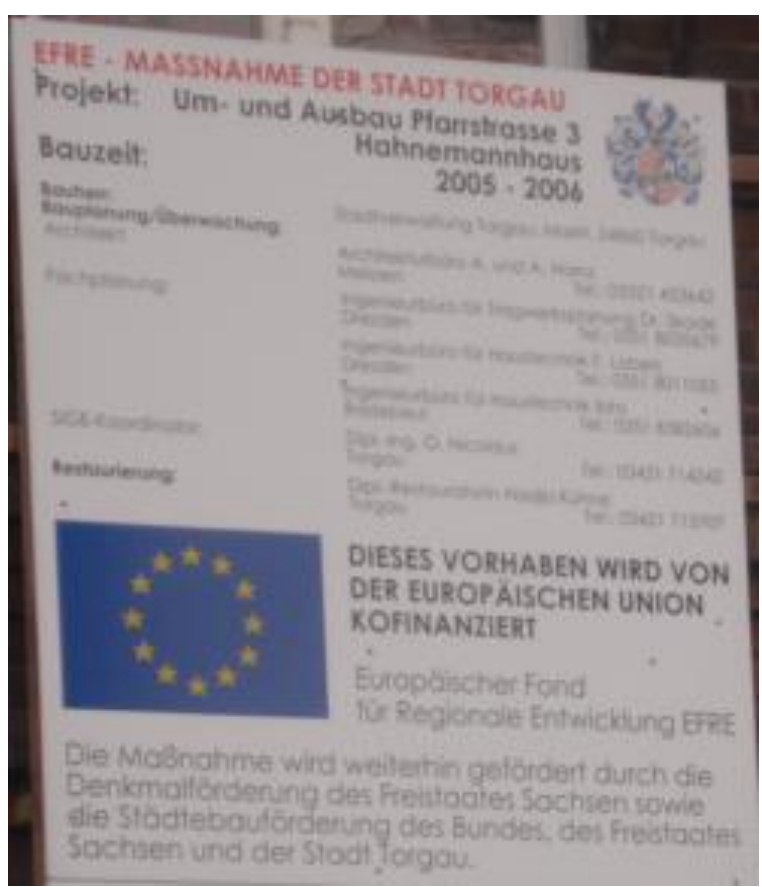

Figure 7: Restoration project of Hahnemann's House

After the special cultural and historical value of the house became known, in 2002/3 the roof and exterior facade were restored, while measures were taken to reinforce the structure overall. The work was undertaken by the current owner, the city of Torgau, under the direction of Hainz Inc., an architectural firm located in Meissen. Noll-Minor, the Torgau restoration studio, was entrusted with securing and restoring the valuable wall and ceiling paintings, as well as with overseeing all renovation measures (figures 6 and 7).

Until October 2007, when Hahnemann House was officially handed over to the International Homeopathic College, there had been put in more than 2.5 million $€$, mainly subsidies from the 
European Community, the Federal Government of Germany and the Saxon State to reconstruct and restore the old part of the building as well as to attach a modern part containing a lift and toilets for visitors (figure 8).

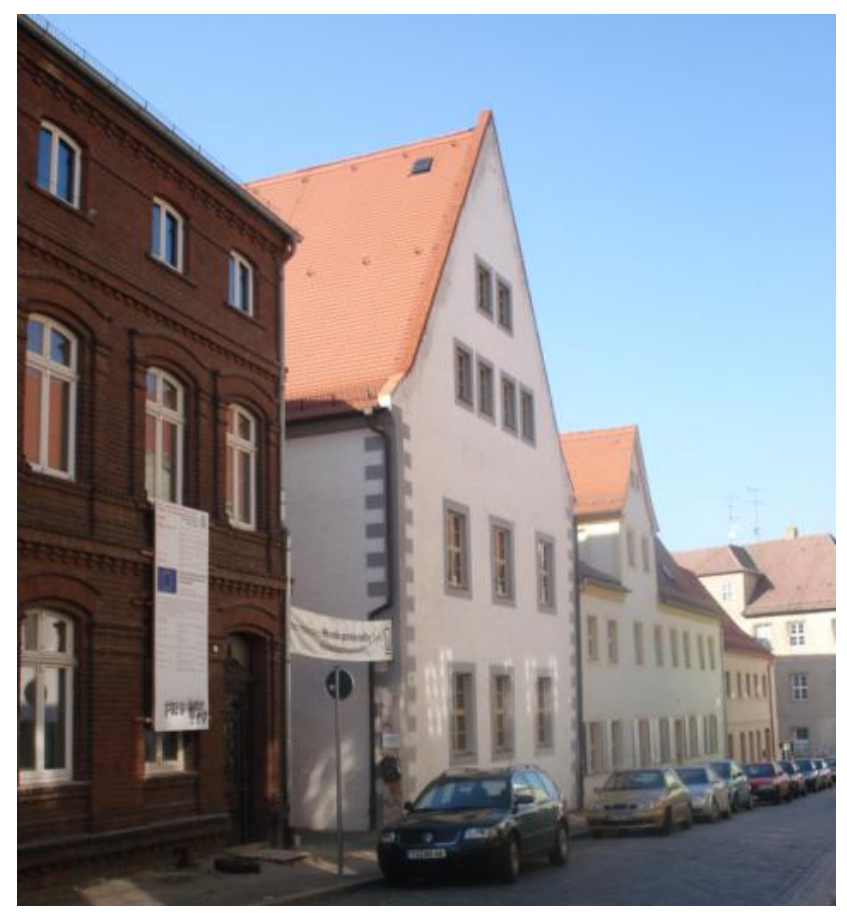

Figure 8: Hahnemann's House (front)

Since then the members of the college have raised more than $50.000 €$ in donations and sold souvenirs and books for the maintenance and equipment of the place. In 2008, the College published The Homeopathic Tour Guide, a book that covers all the historically important places in Saxony and around to be visited by interested people.

\section{Hahnemann's productive years in Torgau}

Although the Hahnemanns had already lived in Eilenburg, in the neighborhood of Torgau, through 1801 and 1802, their journey next led them to Wittenberg and Dessau, before they finally arrived at Torgau in 1804. Here, after 23 years as itinerants, they would settle down for the comparatively long stretch of six-and-a-half years.

Hahnemann's letters plus the Torgau deeds registry provide us with the some details surrounding the transaction. The latter source attests:

"Intending to pursue homeopathic cures among the sick and suffering, in 1804 Dr. Samuel Hahnemann bought the dwelling with its entranceway on Parish Lane near the deaconry from Moebius, the tanner. Previously it belonged to Mehl, the pensioner. Since people were as yet unfamiliar with this manner of cure, it caused quite a sensation to hear that these tiny little globules could help more a whole spoonful of medicine. Belief had its own role to play: many were helped, and many were not. He gained enemies and detractors, and since Torgau had no place for him, and since his circle of influence was so small, he left and went to Leipzig" [4].

It was not before 2005 that the local historian, Dr. Jürgen Herzog dug out the contract of purchase from an archive that states that "the house no. 3 Parish Lane was bought by Dr. Samuel C.F. Hahnemann and his wife, Henriette Hahnemann, nee Küchlerin”.

During the Torgau years, there were some moving episodes in the life of the Hahnemann family. The oldest daughter, Henriette, married, while the one remaining son, Friedrich, went to Leipzig to study. Wilhelmine, their 16-year-old daughter, died in Torgau. Later, during his years in Köthen, Hahnemann would recall more than once those especially wrenching moments, when he was called upon to bury his own children. However, regarding these years in Torgau there are relatively few details known about the Hahnemanns' life.

The above record of deed does not provide the whole picture, which Hahnemann himself drew of his life circumstances during the Torgau years. Unable to expand his circle of influence, he left Torgau - but only under the pressure of external events. After Napoleon had forced his ally, the Saxon King, to erect a fortress on the Elbe, with the choice falling on Torgau, Hahnemann perceived that he would have to leave the city for security reasons. As later would be shown, it was wise foresight that caused him to move elsewhere. In a letter to a friend, dated January 30,1811 , a few days after the king officially ordered the city to be fortified, he wrote:

"And another few words from me. At almost 56 years of age I live in the circle of a family that is dear to me - a wife of rare kindness and seven almost adult, cheerful, educated, well-behaved, innocent daughters, who look after me hand and foot, and who (together with music) gladden my life. Besides, with those patients to whom I am entrusted, almost without exception, I can cure quickly, simply and permanently and thus make a lot of people happy - through Him, who created these marvelous remedies and placed them in my hand. Am I not almost to be envied? But, observe, they are getting ready to make Torgau into a huge royal fortress, wherein the likes of myself cannot hope to live in peace. I have to sell my dear, comfortable free-house - 
and after that go who knows where? Reflect, my dear friend! For the scale to bear such a heavy weight, the all-wise Providence thus places trouble in the other pan." [1]

From this letter it becomes apparent that Hahnemann had no intention of leaving Torgau because he expected a better reception or indeed fame in Leipzig. Just a few weeks before his arrival in the University town, it was not yet clear where his departure would take him. From Leipzig, on December 3, 1811, he wrote:

"The Mars constructor [as Hahnemann called Napoleon] threatened to bury me under the monstrous walls of the Torgau fortification, and so I fled here. Nothing without God's Providence! It grieved me all the same to leave my pretty house and garden, where I believed I had nurtured something for the welfare of humanity" [1].

In Torgau Hahnemann continued with his remedy provings, in all likelihood solely on himself and his family, since his first co-workers, known from the Materia Medica Pura, joined him only in1812, in Leipzig. From the breadth of his publications from 1805 to 1811 it is clear that in Torgau, Hahnemann had sufficient peace for concentrated work and that it was a time without material concerns. (Table 1)

Table 1:. Hahnemann's publications during the Torgau years

"Aesculapius in the scales" (1805)

Fragmenta de viribus medicamentorum positivis sive in sano corpore observatis (1805)

"The medicine of experience" (1805)

"Scarlet fever and French measles: two completely different Diseases" (1806)

"Concerning a substitute for cinchona" (1806)

"What are poisons? What are medicines?" (1806)

"Serious questions concerning the cinchona substitute reported in Issue 12 of the Reichsanzeiger for 1806, and about substitutes generally" (1806)

"Brief investigation of various principles by which medicines heal" (Review of the dissertation by $\mathrm{S}$. Breinersdorf). (1806)

"Hints concerning the homeopathic use of medicines in recent practice" (1807)

"Libellus de Dysenteria" (Review of the book by J.G. Rademacher) (1807)

"Concerning the present lack of non-European drugs" (1808)
"Concerning the substitution of foreign remedies and the superfluous state of which, as declared most recently by the medical Faculty in Vienna" (1808)

"Concerning the value of speculative medical systems..." (1808)

"Summary of a letter to a highly-ranked doctor concerning the much-needed rebirth of medicine" (1808)

"Remarks concerning scarlet fever" (1808) Report of the inquiry (...) into prophylactic measures against scarlet fever (1808) "Concerning the venereal diseases and their cure" (1809)

"To a doctoral candidate in medicine" 1809)

"Instruction concerning the prevailing fever" (1809)

"Signs of the times in standard pharmacology" (1809)

Organon of Rational Medicine (1810)

Materia Medica Pura, Part I (1810)
From the last two items, it is obvious that in Torgau Hahnemann crowned his first period of creativity with two of his most important works, establishing the basis for homeopathic treatment. Also in Torgau, Hahnemann was for the last time paid to translate a book, in this case the pharmaceutical text of Albrecht von Haller, published in1806.

\section{Homeopathy in Saxony, from 1811 to the Second World War}

The history of homeopathy as a topic of public discussion begins with the publication of the first edition of the Organon. Here Hahnemann presented the first ripe fruit of his research extending over 25 years. With this as a stepping-stone, he could also 
venture into academia. Being accepted into the Alma mater at Leipzig was more than a quaint formality. After his proposal for a private homeopathic teaching institute had died away without an echo, he saw no other way to bring his method into the light of day; and thus establish to what extent it could be communicated "according to clearly understood principles" [5].

At the outset, Hahnemann's pupils formed a small, dedicated circle that maintained close personal contact with the master. From 1826 on, after Hahnemann had already left Leipzig for Köthen, they called themselves the Corresponding Society of Homeopathic Physicians. The formal incorporation of the Union for Promotion and Training in Homeopathic Medicine took place in Köthen on August 10, 1829, the anniversary of Hahnemann's graduation. Any physician who practiced homeopathic medicine could become a member of the Union, as well as lay persons who wanted to cooperate in spreading homeopathy. In the same period Hahnemann received the sum of 1,250 thalers as a down payment for a homeopathic hospital. After 1832 the Union called itself the Homeopathic Central Union. Interestingly, the articles of incorporation stipulated that of the 8 elected directors at least 3 had to be residents of Leipzig. In addition to Stapf's Archive, the General Homeopathic Gazette was founded in that same year. It has continued to appear down to this day, thus being the oldest medical journal in the world that has appeared without interruption [6].

Since Stapf was a close friend of Hahnemann and also one of his first students, the Master viewed the appearance of a second publication with some mistrust - all the more so when he was informed (the developments in Leipzig back then being viewed as if from afar), that some doctors were interpreting his teaching in a quite arbitrary way. Hahnemann described the directors of the new organization as "mongrel homeopaths" and from 1833 on the Union convened no longer in Köthen, but rather in Leipzig [6].

Here was also founded the world's first homeopathic hospital. In January 1833 Moritz Müller was appointed director of this institution. The hospital had 24 beds, 12 each for men and women. In the first 8 months, 1,118 day patients received treatment, along with 119 in-patients. Though Müller was certainly an enthusiastic supporter of homeopathy, he had also worked with naturopathic methods, including outdoor exercise. He dared to use these various methods within the confines of a hospital designated as "homeopathic," and for this he was sharply criticized by Hahnemann. On this account, Müller quitted his position. After admonishing his followers to practice homeopathy in strict accordance with the principles he had laid down, the master himself assumed control of the hospital, appointing Dr. Lehmann as a director in 1834 [6].

In 1835, when Hahnemann left Germany for good, the Central Union again took over the hospital. This group was not, however, very adept in appointing a successor. In 1835 it even transferred leadership to a conventional doctor, who had gained his reputation by forging "homeopathic" publications. But in any case, the Central Union was not especially interested in the homeopathic hospital. In 1839, the Union chose Leipzig as the site for its annual general meeting. It was expected that homeopaths from all parts of Germany would travel there to see the hospital. But nobody came [6].

From the beginning, there was clearly no standard for the homeopathic training of doctors, which again and again led to differences of opinion as to the correct way to practice. This was one of the main reasons why there was a lack of response by sick people (this, in turn created financial difficulties). In 1842 the place had to be closed once again.

From 1843 on, a homeopathic polyclinic was held in Leipzig under the direction of Hartmann, a student of Hahnemann, and the above-mentioned Müller. These homeopaths were successful in gaining public support for their facility from the Saxon government, so that they could administer to provide poor people as well.

In addition, the polyclinic also served as a teaching establishment, as Leipzig University has stopped offering a course in homeopathy since Hahnemann's departure. Although health insurance at that time covered homeopathic administrations, the number of Saxon physicians who trained in homeopathy remained quite modest - for the year 1897, for example, only 10 to15 physicians are listed [6].

In the 1890 s, three doctors at the Polyclinic treated between 3,000 and 4,000 patients on a yearly basis. The Polyclinic existed for 100 years, frequently moving from one location to another, until it was totally destroyed by the bombing of Leipzig in 1943. Destroyed also were the Archive of the Central Union and certain original editions and pieces of furniture which Hahnemann had owned.

Compared with the situation in the United States, where a number of Hahnemann's successful students emigrated, and where homeopathic colleges turned out hundreds of graduates per year, in Germany generally (and not only in Saxony) the development of homeopathy stagnated as a form of professional medicine. Since there were no officially recognized teaching facilities, any doctors who learned and practiced genuine homeopathy were 
always kept on the margin. And that is how things remain today.

Beginning at the time of the rift with Hahnemann, the exponents of the so-called "school of critical science" in the homeopathic Central Union always enjoyed superiority in numbers. In point of fact, this was not a school based on the principles Hahnemann laid down for homeopathic medicine, but rather a departure from these. For example, B.A. Vehsemeyer recommended the use of decimal dilutions, because to scientifically trained doctors it would be easier to make a case for such lower preparations. With their striving for recognition from materialistic science, these doctors abandoned the path drew by Hahnemann - and with it also the road to success [1].

On the other hand, in Saxony amongst the doctors of the Central Union, there were enough advocates to set up a homeopathic hospital for themselves - even though there was only a single one in Leipzig from 1888 to 1901 before it had to be closed again on account of financial woes, disorganization and personal in-fighting [7].

There were two other forces which lent some impetus to homeopathy, keeping it alive if only in a feeble sense. From 1870 on, William Schwabe, a very active pharmacist, also carried on a polyclinic in Leipzig. Since in Saxony and in Germany generally there were not enough homeopathic physicians to justify a production centre for genuine remedies, Schwabe went in another direction, which his son of the same name continued into the first half of the $20^{\text {th }}$ century with great success. Schwabe founded a homeopathic publishing house, providing self-help books for the layman, offering home remedy kits with these, and through various publications (for example, the Leipzig Popular Journal of Homeopathy) informing the public in no uncertain terms about the advantages of homeopathy, compared to the dominant medicine of the old school. This one journal appeared monthly with a circulation of 55,000. At the same time, Schwabe marketed all sorts of preparations which today we would characterize as phytotherapeutic. Due to this traditional blending of naturopathy and homeopathy in Saxony, even today the majority of doctors and lay persons cannot distinguish between the two therapeutic systems [7].

Prior to Schwabe, there was a charismatic follower of homeopathy who achieved enormous popularity the lay therapist Arthur Lutze, of Köthen. He had heard of Hahnemann's works and subsequently studied them. He pursued homeopathy with such great zeal, that he created the most modern clinic in Europe, which treated one million patients over a period of 16 years. Although his treatments involved a combination of homeopathy and mesmerism (which Hahnemann expressly recommended in the Organon), Lutze was very controversial for other reasons, among which his new edition of the Organon, which he corrected on his own initiative. Though in actual fact Lutze practiced not in Saxony, but in the Grand Duchy of Anhalt-Koethen, a few kilometres from the Saxon border, he nevertheless exerted an immense impact on a whole generation of contemporary homeopathic physicians [7].

Since conventional medicine at that time was known to be profit-oriented, for some time homeopathy enjoyed a considerable following among ordinary people, who could not afford expensive procedures. In Saxony there were more than 130 homeopathic lay societies, up until their dissolution in the Nazi period. This was due less to the efforts of the Central Union (which, rechristened as the Central German Union of Homeopathic Physicians, soon excluded lay persons, contrary to Hahnemann's practice) - and more to the spread of basic homeopathic philosophy through publications like those of Schwabe and Lutze, as well as through lectures by lay homeopaths.

In any case, because there was an absence of expert supervision, the homeopathy practiced in Saxony was often a colorful mixture of true homeopathic treatment, together with traditional folk-healing, modern naturopathy, and various forms of spiritual healing.

\section{Homeopathy in Saxony, 1933 to 1989}

Due to the lack of physicians in the war-time, the Nazi government passed an Act Concerning the Practice of Medicine without a License. This stated that existing lay practitioners, who had demonstrated before a board of medical examiners that they knew enough about the fundamentals of medicine to present "no danger to the health of the public," could practice medicine under certain stipulations; and that they were to be designated as Heilpraktiker; that is, healing practitioners [8]. After the fall of the Nazi dictatorship, the German Democratic Republic (GDR) government struck down all laws passed during the Nazi period including the Medical Practitioner Act. Thus, in Saxony for the next 40 years there were only a handful of homeopaths: the few homeopathic doctors who had survived the war and were not yet retired and those who from 1939 on were called "healing practitioners." The latter had busy practices, but officially their knowledge could not be passed on. In the GDR, an ideology of strict materialism prevailed, by which any non-physical medicinal actions were precluded by decree.

Typical of the overall inconsistency and confusion of the socialist era was the fact, however, that a 
portion of the "Leipzig Drug Manufactory" (previously "Willmar Schwabe's Pharmaceutical Works") produced homeopathic tablets such as Arnica, Belladona and Aconitum in dilution 4x, until production was suspended in 1991. Additionally, these remedies were openly authorized for sale in the pharmacies.

\section{Homeopathy in Saxony following the German reunification}

Stimulated by contacts with doctors and healing practitioners in West Germany, interest in homeopathy soon reawakened in the Eastern area. The first homeopathic courses began almost simultaneously around 1991, organized by the German Central Union for Homeopathic Physicians and the Leipzig's Faculty for Veterinary Medicine, supported by the Veronika and Karl Carstens Foundation. While the very learned Swiss doctor, Dario Spinedi, was teaching in Machern, in Leipzig several West German veterinarians (Achim Schuette, among others) and healing practitioners (above all, Klaus Thon from Frankfurt/Main) were also holding lectures.

Since then, the homeopathic doctors and the nonmedical homeopaths have gone separate ways, just as the statute of the German Central Union of Homeopathic Physicians presaged. Thus, in Saxony the already meager base for homeopathy remains divided. Currently, there are roughly 300 doctors in Saxony who have earned the additional designation of "Homeopathy" through attending 300 hours of instruction. However, the designation "Homeopathy" is awarded by administrators at the State Medical Board of Registrations - people without a clue on homeopathy - so there still exists no effective standard for qualifying homeopathic doctors. As one of those who actually participated in Machern as an instructor, Uwe Friedrich, a homeopathic physician, writes on this very point:

"The current problem for homeopathy in Germany is that at the present time the not very high educational standards for homeopathy as a physician's designation provided by the Medical Council have been slashed to an intolerably low level. In this way the designation becomes more a stigma of ignorance than a sign of special qualification"[8].

This situation also explains why, of the hundreds of Saxon doctors having the designation "Homeopathy," fewer than a dozen practice as classical homeopaths. All the rest tend to confuse their patients and bring homeopathy into disrepute, because often "Homeopathy" may be seen on the shingle, whereas there is none to be had in the office. Among those who set themselves up as healing practitioners, the situation is scarcely better. At their own schools many take some homeopathic lectures over a few weekends, and then inscribe "Homeopathy" among several other healing modalities on their office shingle. Until now, no one has asked whether they were really qualified to do so.

Beginning in 1998, strenuous efforts have been made in Germany to raise the standard of homeopathic education to a uniformly higher level, and to do this in a way that ensures transparency on behalf of the patient. Representatives from some 70 teaching institutes from all over Germany deliberated for five long years, before establishing the diploma of the Foundation for Homeopathic Certification (SHZ). To earn this diploma, homeopaths must demonstrate at least 1,800 hours training, as well as perform clinical rounds under the supervision of experienced homeopaths. The diploma is not granted for life, but must be reapplied for every two years.

Keeping with the spirit of Hahnemann, the International College of Homeopathy at Hahnemann's House in Torgau was founded in 2003 (Figure 9). It is concerned with the training and continual education of homeopaths, strictly according to the method of Hahnemann and his genuine followers. It is also devoted to restoring and utilizing Hahnemann's House as a listed historical building, to serve once again as a centre for homeopathic therapy, teaching and research.

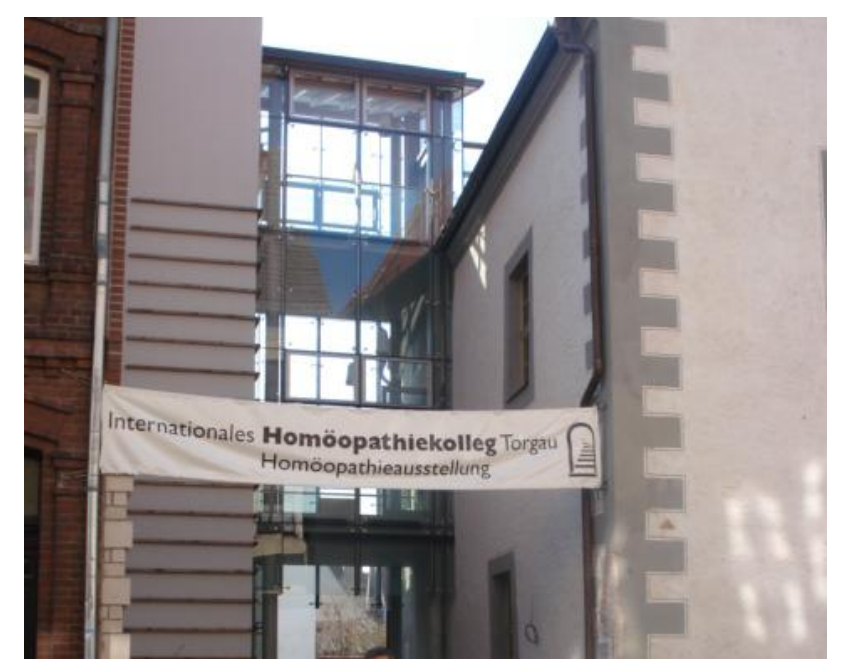

Figure 9: International College of Homeopathy at Hahnemann's House in Torgau

After restoration is complete, it is foreseen that Hahnemann's House and the operative teaching facilities it hosts will be incorporated as a foundation, in order for the public to continue to use 
the building and the knowledge developed there in perpetuity. An artistic representation (wmv format) can be shown at http://www.feg.unesp.br/ ojs/index.php/ijhdr/article/ view/339/388.

The International Homeopathic College keeps close cooperation with the following institutions: Professional Association of Classical Homeopaths (VKHD) and the Foundation for Homeopathic Certification; other homeopathic teaching- and research institutes, primarily in Saxony and the bordering German states (among others, Meissen's Hahnemann Centre, InHom at Koethen, the ProLife Clinic at Greiz); homeopathic foundations such as the Veronica and Karl Carstens Foundation and the Robert Bosch Foundation at Stuttgart; lay movements, such as Hahnemannia; homeopathic publishers, book sellers and journals; international teaching- and research institutes with similar goals; and the city of Torgau, with regards to public relations and the vibrant tourist activity in the city, which comes with international exchanges, at which point the house at 3 Parish Street becomes integrated with Torgau's museum scene.

\section{Acknowledgments}

The author expresses his gratitude to Dr. Juergen Herzog, Torgau Historical Society, for his research; to Ms Andrea Staude, the mayor of Torgau, for her enthusiastic support of our project; and to Matthias Schulze, architect and photographer, for his professional services. Special thanks are owed to Dr. Egon Krannich, my colleague and publisher, whose experience, practicality and sharp eye have transformed a mass of material into the present paper. I last but not least acknowledge Douglas Smith, from Minden, Ontario (Canada) for the translation of the manuscript.

\section{References}

[1] Haehl R. Samuel Hahnemann: sein Leben und Schaffen. Leipzig: Willmar Schwabe, London: Homoeopathic Publishing Co; 1922.

[2] Zentralarchiv Wernigerode; 1804 Contract of Purchase between Avokat Ziegler and Dr. Samuel Hahnemann concerning the property Torgau, Pfarrgasse 3.

[3] Noll-Minor M. Das Freihaus Pfarrstr 3. In: Torgau: Stadt der Renaissance, editor. Von Stockhausen T. Dresden: Michel Sandstein Verlag; 2003.

[4] Lange KH. Dr. Christian Friedrich Samuel Hahnemann: Begruender der Homoeopathie. Torgau; 1998.

[5] Hahnemann S. Organon der Heilkunst. 6th ed. Berg am Starnberger See: O -Verlag; 1985.

[6] Haehl E. Geschichte des Deutschen Zentralvereins homoeopathischer Aertze. Leipzig: Verlag Dr. Willmar Schwabe; 1929.

[7] Alex P. Wo das Organon entstand: Hahnemanns Haus in Torgau, damals und heute. Grimma: Edition Krannich; 2004.

[8] Friedrich U. Zeitschrift fuer Klassische. Homeoepathie, 2003.

\section{(c) EY-NC-ND Licensed to GIRI}

Support: see acknowledgements section.

Conflict of interest: author declare there is no conflict of interest

Received: 05 Apr 2009; Revised 10 Jun 2009; Published: 30 Jun 2009

Correspondence author: Peter Alex, alex-homeopathics@web.de

How to cite this article: Alex P. Birthplace of Homeopathy: Hahnemann's House in Torgau, Then and Now. Int J High Dilution Res [online]. 2009 [cited YYYY Month dd]; 8(27): 70-79. Available from: http://www.feg.unesp.br/ ojs/index.php/ijhdr/article/view/339/387. 